\title{
Welcome to Biosis: Biological Systems
}

\section{Dr. Gareth Dyke}

aUniversity of Debrecen, Hungary. Email: gareth.dyke@vocs.unideb.hu

(C) The Author(s) 2020

Dear Readers and Authors

We are proud to welcome you to the first issue of Biosis: Biological Systems.

Our journal is an international, fully peer-reviewed and Committee on Publication Ethics (COPE) compliant open access Journal that is published entirely online. Our goal is to promote interdisciplinary approaches in Biology and Medicine, at the interface between organismal and the processes of organic evolution in the broadest sense.

We welcome contributions (usually up to a maximum of 12,000 words) that illustrate the unifying concepts of systems biology with evidence, either observational or theoretical, from any relevant field of the biological sciences. Biosis: Biological Systems emphasises the study of biological situations using a variety of tools, including mathematical and general systems methods. The Journal solicits original research papers and review articles across the range of biological systems, living and fossils.

We offer rapid, peer-reviewed online publication and access to an expert editorial team of specialists from around the world. Our emphasis is on publishing quality papers rapidly and then making them freely available to researchers worldwide.

Why not consider submitting a paper to Biosis: Biological Systems? Get in touch with our team to find out more!

Publisher's note: Eurasia Academic Publishing remains neutral with regard to jurisdictional claims in published maps and institutional affiliations.

Open Access This article is licensed under a Creative Commons Attribution-NoDerivatives 4.0 International (CC BY-ND 4.0) licence, which permits copy and redistribute the material in any medium or format for any purpose, even commercially. The licensor cannot revoke these freedoms as long as you follow the licence terms. Under the following terms you must give appropriate credit, provide a link to the license, and indicate if changes were made. You may do so in any reasonable manner, but not in any way that suggests the licensor endorsed you or your use. If you remix, transform, or build upon the material, you may not distribute the modified material.

To view a copy of this license, visit https://creativecommons.org/licenses/by-nd/4.0/. 